\title{
フェニトインの剤形変更に伴う血清中濃度の上昇：症例と要因の解析
}

山口智子, ${ }^{*}, a$ 向井志乃, ${ }^{a}$ 魚谷茂雄, ${ }^{b}$ 大谷壽一, ${ }^{c}$ 澤田康文 ${ }^{c}$

\section{An Increase in Serum Phenytoin Concentration by Changes of Dosage Form: Case Reports and Its Mechanism}

\author{
Tomoko Yamaguchi, ${ }^{*, a}$ Shino MUkaI,${ }^{a}$ Shigeo Uotani, ${ }^{b}$ \\ Hisakazu OHTANI, ${ }^{c}$ and Yasufumi SAWADA ${ }^{c}$ \\ Department of Hospital Pharmacy, Isahaya Ryoiku Center, ${ }^{a}$ and Internal Medicine, \\ Isahaya Ryoiku Center, 724 Uki-machi, Isahaya 854-0121, Japan and Graduate \\ School of Pharmaceutical Sciences, Kyushu University, c 3-1-1 Maidashi, \\ Higashi-ku, Fukuoka 812-8582, Japan
}

(Received November 28, 2001; Accepted February 22, 2002)

\begin{abstract}
Phenytoin (PHT) exhibits nonlinear pharmacokinetics in the therapeutic range. Therefore a slight increase in dose may lead to considerable elevation of the serum PHT level. Although its bioavailability is dependent on the formulation, bioequivalence is considered to be preserved between the three major formulations, of tablet, $97 \%$ fine granules, and 10 $\%$ powder. However, we experienced many cases of increases serum PHT concentration after changes in formulation from $97 \%$ fine granules to $97 / 4 \%$ hospital-made fine granules, and from the latter to $10 \%$ powder. Retrospective analysis revealed that these alterations were accompanied by $55 \%$ and $16 \%$ increases in the serum concentration-to-dose ratio of PHT, respectively. We investigated the factors of this increase by analyzing the weight of remaining powder in a package and the PHT content of each formulation. Each package of PHT formulation prepared with $97 \%$ fine granules and $10 \%$ powder was unsealed, and the contents were weighed to calculate the rate of recovery. The rate of ingestion was estimated by correcting the rate of recovery by PHT strength (i. e., 1.0 for $10 \%$ powder and 0.97 for fine granules). The rates of recovery and ingestion for $10 \%$ powder were $13 \%$ and $16 \%$ higher than those for $97 \%$ fine granules, respectively $(p<0.01)$. In conclusion, Changing the PHT formulation from $97 \%$ fine granules to $10 \%$ powder may lead to a considerable increase in the serum PHT concentration and possibly induce PHT toxicity.
\end{abstract}

Key words—— phenytoin; serum concentration; dosage form

\section{背 景}

フェニトイン (PHT) は古くから使用されてい る抗てんかん薬であり，欠神発作を除くすべての発 作に対して有効性を示し，最も広範に使用されてい る抗てんかん薬の 1 つである。一方で, PHTはそ の体内動態が非線型性を示すことが広く知られてい る。すなわち, PHT の血清中濃度が，低濃度域で は濃度と投与量の間に比例関係が認められるが, 有 効血清中濃度（10-20 $\mu \mathrm{g} / \mathrm{ml} ）$ 付近では, 投与量の わずかな増加によって血清中濃度は急激に上昇し容 易に中毒域に到達する。血清中濃度が $20 \mu \mathrm{g} / \mathrm{ml}$ を

a) 諌早療育センター薬局, b) 同内科, c) 九州大学大学院 薬学研究院臨床薬学講座

e-mail: gzw05275@ nifty.ne.jp
超えると, 複視, 眼球振盪, $30 \mu \mathrm{g} / \mathrm{ml}$ を超えると 運動失調, 歩行困難, $40 \mu \mathrm{g} / \mathrm{ml}$ を超えると傾眠, 構音障害, $70 \mu \mathrm{g} / \mathrm{ml}$ を超えると意識障害などの重

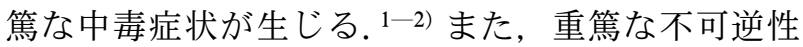
の副作用として, 小脳萎縮を来たした症例が報告さ れている. ${ }^{3-4)}$ このような体内動態学的, 毒性学的 な特性のために, PHT の投与にあたっては血清中 濃度のモニターを行いつつ，十分な注意のもとで投 与量の調節を行うことが必須とされている.

また，PHT の体内動態は剤形による影響を受け ることが報告されている. ${ }^{5)}$ 中でも PHT 末は吸収 率が低いことが知られているが，本邦においては， 現在ではPHT 末は使用されていない。一方, 現在 本邦で使用されている PHT 錠, $97 \%$ 細粒，10 倍

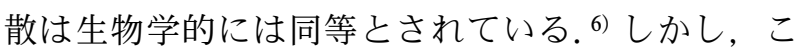


れらの同等性は, PHT 錠, 10 倍散間の比較におい ては, PHT として $100 \mathrm{mg}$ づつ, また PHT 錠と 97 $\%$ 細粒の比較においては, PHT として $200 \mathrm{mg}$ 相 当の錠と，製剤量として $0.2 \mathrm{~g}$ (PHT として 194 mg）の 97\% 細粒をそれぞれ単回経口投与し，血清 中濃度の時間推移と $C_{\max }$ (最高血清中濃度), 及び AUC（血清中濃度一時間曲線下面積）を比較する ことにより検討されたものにすぎない. $\left.{ }^{6}\right)$ さらにこ れらの試験における $C_{\max }$ は $2-4 \mu \mathrm{g} / \mathrm{ml}$ であること から, その生物学的同等性は, 線型動態を示す範囲 内においてしか検討されていないことを意味する。

したがって, これらのデー夕は, 有効血清中濃度付 近における各製剤の生物学的同等性を十分に保証す るものではないと考えられる.

また，PHT200 mg に相当する錠剤と 10 倍散は, PHT を $194 \mathrm{mg}$ 含む $97 \%$ 細粒と同等のものとして 比較されている。このため, $97 \%$ 細粒から錠又は 10 倍散への剂形変更を行つた場合, 製剂間で生物 学的利用率に差がないと仮定しても, PHT として は約 3\%の増量となる. したがつて, 非線型動態を 示す有効血清中濃度を与えるための投与量範囲で は，この約 3\% の増量が血清中濃度に大きな影響を 与える可能性も否定できない。 さらに，97\% 細粒 と 10 倍散を比較すると, 同用量の PHT を投与す る場合の服用製剂量は後者が前者の 10 倍となる.

このため分包紙への残留製剤量が同量であるとする と, 実際に体内に摂取される PHT 量は 10 倍散を 用いた場合のほうが多くなると考えられる。

諌早療育センター（当施設）などの重症心身障害 児（者）施設においては, 患者における散剤の使用 量が多く, かつ誤嚥防止などの観点から摂取する散 剤の全量を最小限にすることが求められている. 当 施設においてはPHT として $97 \%$ 細粒のみを使用 していたが, 微量処方への対応が必要となったた め, 院内調製 PHT4 倍細粒（97\% 細粒を乳糖を用 いて 4 倍に希釈した院内製剂）へ，続いて市販の PHT10 倍散へと半年間で二回の剂形変更を行っ た.この剤形変更に伴い, $\mathrm{C} / \mathrm{D}$ 比（血清中濃度/投 与量比) $[(\mu \mathrm{g} / \mathrm{ml}) /(\mathrm{mg} / \mathrm{day} / \mathrm{kg})]$ の上昇を認めた 症例を多数経験した。 そこで本報告においては, 典 型的な症例を紹介するとともに, PHT の剂形変更 が $\mathrm{C} / \mathrm{D}$ 比に及ぼす影響について遡及的に調查する ことを目的とした。ささら，剤形変更で $\mathrm{C} / \mathrm{D}$ 比に
変動を来たした要因について，97\% 細粒と 10 倍散 の PHT 含量の違い, すなわち $97 \%$ 細粒の PHT 含 量を $100 \%$ とみなして計算したことによる約 3\% の 増量, 及び服用製剂量の増加による分包紙への PHT 残留量の変化の観点から, 分包試験を行い検 討することを目的とした.

\section{症例}

症例 1 （Fig. 1A） 30 歳女性。体重 $25.6 \mathrm{~kg}$. 脳性麻痺, てんかん, 精神遅滞, 未熟児網膜症, 並 びに慢性 B 型肝炎のため, 1984 年 4 月より当施設 に入所していた。 入所時処方はフェノバルビタール $80 \mathrm{mg} / \mathrm{day}$ の経管投与のみであった. 同年 10 月よ り PHT $97 \%$ 細粒が $0.04 \mathrm{~g} /$ day（製剤量）追加され た. その後投与量は漸増され，2000 年 4 月からは, $97 \%$ 細粒 $0.19 \mathrm{~g} / \mathrm{day}$ (製剤量) とフェノバルビター ル $70 \mathrm{mg} /$ day（いずれも経管投与）により，発作は 良好にコントロールされていた。この時, PHT97 \% 細粒は賦形を行わずに単剤で分包していた。 2000 年 10 月 16 日の血清中 PHT 濃度は $22 \mu \mathrm{g} / \mathrm{ml}$ であった。 2000 年 10 月における併用薬は, ピコス ルファートナトリウム（頓用）のみであった. 2000 年 10 月 20 日に PHT としての投与量を変更するこ となく 4 倍細粒に剂形変更した。 12 月 15 日の血清 中濃度は $30.1 \mu \mathrm{g} / \mathrm{ml}$ と上昇していたため, 4 倍細 粒の投与量は $0.68 \mathrm{~g} /$ day $(97 \%$ 細粒 $0.17 \mathrm{~g} /$ day 相 当）へと減量された。平素は夜間良眠であったが, 減量を要したころから夜間不眠が発現し，12月末 まで続いた。 2001 年 1 月 20 日に発作を認めたた め，この時血清中濃度を測定したところ，7.7 $\mu \mathrm{g} /$ $\mathrm{ml}$ にまで低下していた。この際, PHT の投薬や消 化管の吸収に影響を及ぼすような要因は見出されな かった。 原因は不明であるが, この患者は, 過去に $10 \mathrm{mg} /$ day 程度の投与量変更時にも血清中濃度の大 幅な変動を来した既往があった。このため, 10 倍 散への剂形再変更により血清中濃度が再度上昇する 危険性を見越して，投与量を変更しないまま，1月 22 日に PHT10 倍散 $1.7 \mathrm{~g} /$ day（PHT として 170 $\mathrm{mg} /$ day）に剂形を変更した。 その後発作は消失し たものの，2 月 28 日には血清中濃度が $31.7 \mu \mathrm{g} / \mathrm{ml}$ と再び上昇していた。 そのため, 投与量を PHT と して $150 \mathrm{mg} /$ day 乞と減量した. 減量後, 啼泣が頻 繁にみられるようになり，3 月中旬まで続いたため, 
(A)
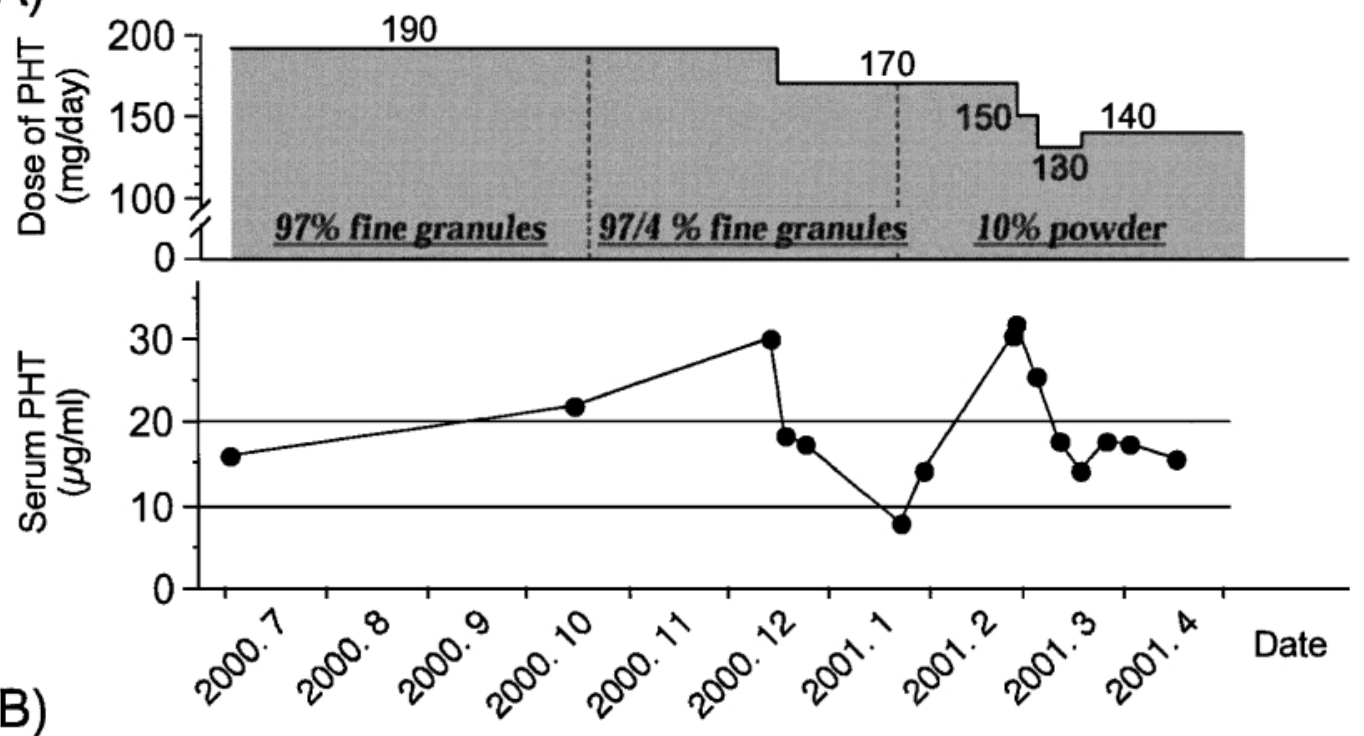

(B)

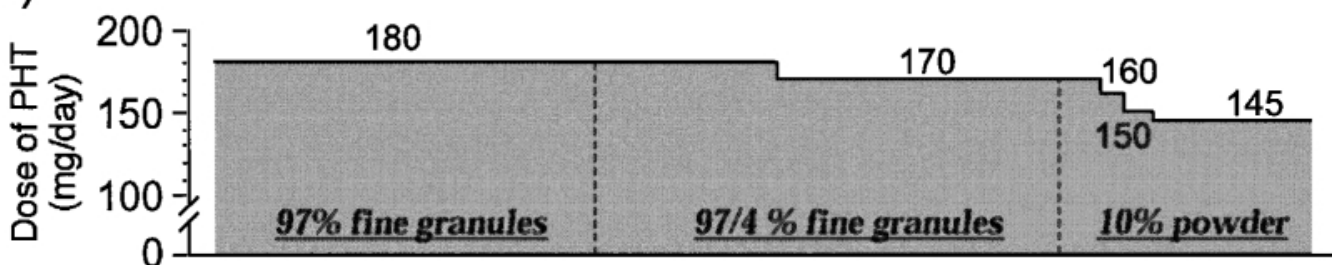

(C)
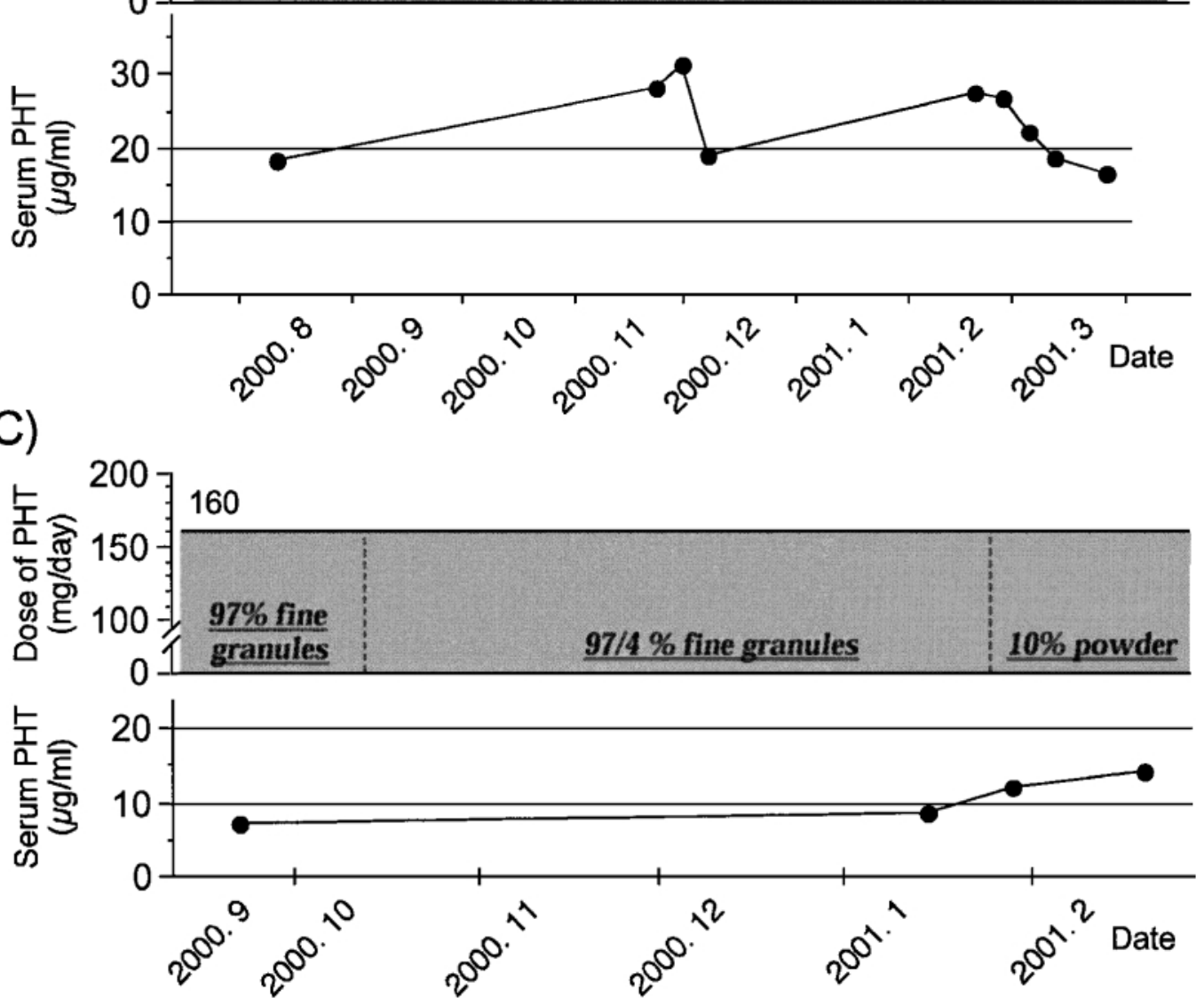

Fig. 1. Three Typical Cases of Increase in Serum PHT Concentration by the Alternation of Dosage Form

(A) a case of 30-years-old woman with cerebral palsy, epilepsy, mental retardation, retinopathy pf prematurity and chronic hepatitis B. (B) a case of 42 -yearsold man with sequela of tuberculous meningitis, epilepsy and mental retardation. (C) a case of 17-years-old woman with nodular sclerosis, right hemiplegia and epilepsy. The $97 / 4 \%$ fine granules was prepared in Isahaya Ryoiku Center Hospital using $97 \%$ PHT fine granules and extra fine crystal lactose. 
3 月 19 日, 再び投与量を PHT として $140 \mathrm{mg} / \mathrm{day}$ まで減量した。その結果, 血清中濃度は $15-20 \mu \mathrm{g} /$ $\mathrm{ml}$ で安定した。この間, 併用薬の変更はなく, 肝 機能の悪化などは認められなかった。 また，フェノ バルビタールの血清中濃度は治療濃度域内で安定し ていた。

症例 2 （Fig. 1B） 42 歳男性. 体重 $30.3 \mathrm{~kg}$. 結核性髄膜炎後遺症, てんかん並びに精神遅滞のた め, 1984 年 6 月より当施設に入所していた. 1998 年 1 月より 2000 年 10 月まで, PHT97\% 細粒 0.18 $\mathrm{g} /$ day（製剂量）の経口投与により，血清中濃度は $17-18 \mu \mathrm{g} / \mathrm{ml}$ にコントロールされており, 発作頻 度も月 1 回程度と安定していた。 2000 年 10 月にお ける併用薬は, フェノバルビタール $80 \mathrm{mg} / \mathrm{day}$, カ ルバマゼピン $600 \mathrm{mg} / \mathrm{day}$, アルファカルシドール $0.1 \mu \mathrm{g} / \mathrm{day}$, プラバスタチンナトリウム $10 \mathrm{mg} / \mathrm{day}$ 並びに重質酸化マグネシウム $0.3 \mathrm{~g} /$ day であった. この時, PHT97\% 細粒は, フェノバルビタール 10 \% 散およびカルバマゼピン $50 \%$ 細粒と混合して分 包を行っていた。 2000 年 10 月 20 日にPHT として の投与量を変更することなく 4 倍細粒に剂形変更し た. 12 月 1 日の血清中濃度が $31.2 \mu \mathrm{g} / \mathrm{ml}$ と上昇し ていたため, 4 倍細粒の投与量は $0.68 \mathrm{~g}$ (97\% 細粒 $0.17 \mathrm{~g} /$ day 相当）へと減量された。 その結果, 血清 中濃度は治療濃度域にまで低下した。 2001 年 2 月 8 日に 10 倍散 $1.7 \mathrm{~g} /$ day（PHT として $170 \mathrm{mg} /$ day） に剂形変更したところ，2 月 19 日に血清中濃度が $27.2 \mu \mathrm{g} / \mathrm{ml}$ と再び上昇していた。 そのため 10 倍散 の投与量を 2 月 21 日に $160 \mathrm{mg} / \mathrm{day}, 2$ 月 27 日に

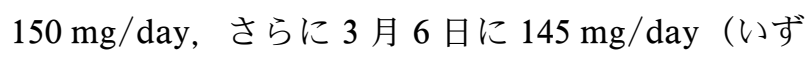
れも PHT として）へと漸減した. その結果, 血清 中濃度は $15-20 \mu \mathrm{g} / \mathrm{ml}$ で安定した。この間, PHT 中毒を疑わせる他覚症状はなく, 発作頻度も変化は なかった。白癬悪化のためイトラコナゾール 100 $\mathrm{mg} / \mathrm{day}$ が 2 月 21 日より追加された他は, 併用薬 に変更はなかった. カルバマゼピンの血清中濃度は $4-4.5 \mu \mathrm{g} / \mathrm{ml}$, フェノバルビタールの血清中濃度は $25.3-28.2 \mu \mathrm{g} / \mathrm{ml}$ で安定していた.

症例 3 （Fig. 1C） 17 歳女性. 体重 $25.5 \mathrm{~kg}$. 結節性硬化症, 右片麻痺, 並びにてんかんのため, 1988 年 9 月 1 日より当施設に入所していた. 入所 時処方は, フェノバルビタール $20 \mathrm{mg} / \mathrm{day}$, カルバ マゼピン $150 \mathrm{mg} / \mathrm{day}$, バルプロ酸 $600 \mathrm{mg} / \mathrm{day}$ 並
びにクロナゼパム $2 \mathrm{mg} / \mathrm{day}$ の経口投与であった. 同年 12 月より PHT97\% 細粒 $0.03 \mathrm{~g} /$ day（製剂量） が追加された．その後投与量は $0.16 \mathrm{~g} / \mathrm{day}$ (製剂量) に増量され，1999 年 12 月より 2000 年 10 月まで, 血清中濃度は 7-10 $\mu \mathrm{g} / \mathrm{ml}$ で推移していた。この 間, 発作は比較的良好にコントロールされていた。 2000 年 10 月における併用薬は, カルバマゼピン $500 \mathrm{mg} / \mathrm{day}$, バルプロ酸 $700 \mathrm{mg} / \mathrm{day}$, クロナゼパ ム $0.5 \mathrm{mg} / \mathrm{day}$, レボチロキシンナトリウム $50 \mu \mathrm{g} /$ day 並びに重質酸化マグネシウム $0.3 \mathrm{~g}$ /回, 及びピ コスルファートナトリウム液（いずれも頓用）であ った.この時, PHT97\% 細粒は, カルバマゼピン $50 \%$ 細粒及びクロナゼパム $0.5 \%$ 細粒と混合して 分包していた. 2000 年 10 月 12 日にPHT としての 投与量を変更することなく 4 倍細粒に剂形変更した が, 血清中濃度及び臨床症状に著名な変化はなかつ た。 2001 年 1 月 25 日にPHT10 倍散 $1.6 \mathrm{~g} /$ day

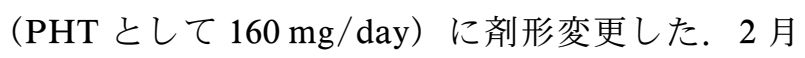
11 日ごろより, 数回の嘔吐がみられ, 傾眠傾向が 認められた。 2 月 20 日の血清中濃度は $14.1 \mu \mathrm{g} / \mathrm{ml}$ とやや上昇していたが, 投与量は変更されなかつ た.この間, 2001 年 1 月 30 日にレボチロキシンナ トリウムが $67.5 \mu \mathrm{g} /$ day に増量された他は, 併用薬 に変更はなかった. カルバマゼピンの血清中濃度は $8.4-14.1 \mu \mathrm{g} / \mathrm{ml}$, バルプロ酸の血清中濃度は 56.8 $-63.9 \mu \mathrm{g} / \mathrm{ml}$ と安定しており, 発作は良好にコント ロールされていた。

\section{方法}

1. 血清中濃度推移の解析 当施設に, 2000 年 4 月一2001 年 4 月に入所中で, 当該期間に継続 的に PHTを経口投与されていた 52 名の患者を対 象とした。なお，採血管は血清分離用スピッツ，ク ロットチューブ A（極東製薬工業，東京）を用い, PHT 血清中濃度の測定はすべて蛍光偏光免疫測定 法（TDX，ダイナボット，大阪）にて行った。 各 患者において, 以下の 4 期における血清中濃度デー 夕を遡及的に収集し, その時点での体重及び投与量 を調査した。 採血時間は各患者において，4 期にわ たり同時刻であり, 対象とした患者のうち 10 名に ついては午前 10 時 30 分, 他の患者については早朝 空腹時であった。また 4 倍細粒は, $97 \%$ 細粒 $25 \mathrm{~g}$ と EFC (Extra Fine Crystal) 乳糖 $75 \mathrm{~g}$ を, 調剂用 
ミル（村中医科機械，大阪）を用いて混和し調製し た.

1） PHASE I（97\% 細粒使用時）：4 倍細粒への剂 形変更直近（最大約 3 力月前）に測定された定常状 態にある血清中濃度.

2) PHASE II（4 倍細粒使用時）：4 倍細粒剂形変 更後の定常状態における血清中濃度. ただし, 定常 状態に至る前に剤形が 10 倍散へ変更された場合は 4 倍細粒使用時の血清中濃度の最高値.

3） PHASE III（10 倍散使用時投与量調節前）：剂 形変更後 3 週間以上経過した時点で測定した血清中 濃度（速やかに投与量変更が行われた 2 名について は 12 日及び 15 日目の血清中濃度)。

4） PHASE IV（10 倍散使用時投与量調節後）：投 与量調節後 15 日間以上経過した血清中濃度。な お，投与量が変更されなかつた患者については， PHASE III のデータをそのまま用いた.

これらのデータから各時点における $\mathrm{C} / \mathrm{D}$ 比を算 出した。同時に併用抗てんかん薬，主病名，痤攣頻 度, 及び投与経路（経口又は経管）についても調査 した. 有意差検定は, 分散分析（ANOVA）及びこ れに引き続く Bonferroni の検定により行った.

2. 分包試験 PHTの 1 日量が, $100 \mathrm{mg}, 200$ $\mathrm{mg}, 300 \mathrm{mg}$, 又は $400 \mathrm{mg}$ の場合を想定し, $97 \%$ 細 粒又は 10 倍散を用いてそれぞれ 7 日分秤量した. すなわち $100 \mathrm{mg}$ の場合，それぞれ $97 \%$ 細粒 $0.7 \mathrm{~g}$ 又は 10 倍散 $7 \mathrm{~g}$ を秤量した。秤量は調剤用電子天 秤（LB-300H，高園産業，大阪）を用いた。これ を分包機（PACK MATE $\alpha 42$, 高園産業）を用い て 21 包に分包した。これは, 当施設において通常 の調剤に用いているものであり, ヘラでならして手 動で分割する方式の分包機である.

それを 1 包づつ切り離し，はさみで開封して 7 日 分の総量を回収し, 調剂用電子天秤で重量を秤量し た. 分包紙としては, PACK MATE 用分包紙のダ イヤマット及びグラシン（高園産業）についてそれ ぞれ行った.

回収した重量から回収率を求め, これに $97 \%$ 細 粒についてはPHT の含有率 0.97 を, 10 倍散につ いては 1.0 を乗じて，それぞれ実際に投与される量 に対応するPHT の摂取率を算出した. 回収率, 摂 取率についてそれぞれ，剂形，用量及び分包紙の 3 つの因子について三元配置の分散分析により有意差

検定を行った.

結果

1. 血清中濃度推移の解析 当該期間にPHT97\% 細粒を処方されていた 52 名の患者は，2000 年 10 月中旬に 4 倍細粒へ，また 2001 年 1 月一2 月にか けて 10 倍散へと剂形変更されていた。これらの患 者のうち, 経口摂取が困難になり注射へと剂形が変 更されたために比較ができなかつた患者等，5名を 除外した 47 名について解析を行つた。 これらの患 者の背景を Table 1 に示す.

製剤の剂形変更に伴う PHT の C/D 比の推移を Fig. 2 に示す。C/D 比は, PHASE I (97\% 細粒使 用時), PHASE II (4 倍細粒使用時), PHASE III (10 倍散使用時投与量調節前), PHASE IV（10 倍 散使用時投与量調節後）において，それぞれ 2.01 $\pm 1.14 ， 3.12 \pm 1.68 ， 3.62 \pm 1.74$ ，及び $3.20 \pm 1.58 \%$ (平均値士標準偏差) であった. $97 \%$ 細粒から 4 倍 細粒，4倍細粒から 10 倍散への剂形変更におい て，いずれも $\mathrm{C} / \mathrm{D}$ 比は有意に上昇した（ $p<$ 0.001 )。うち 31 名（約 66\%）の患者で減量を要し,

Table 1. Background of Patients

\begin{tabular}{|c|c|c|}
\hline \multirow[t]{2}{*}{ Sex } & Male : & 33 \\
\hline & Female : & 14 \\
\hline Age (years) & & $35.6 \pm 11.0^{*}$ \\
\hline Body weight (kg) & & $39.1 \pm 9.6^{*}$ \\
\hline \multirow[t]{5}{*}{ Disease $(\mathrm{s})$} & Cerebral palsy : & 21 \\
\hline & Epilepsy : & 39 \\
\hline & Lennox syndrome : & 6 \\
\hline & $\begin{array}{l}\text { Mental retarda- } \\
\text { tion: }\end{array}$ & 45 \\
\hline & Others : & 26 \\
\hline \multirow[t]{5}{*}{ Frequency of seizure } & Free : & 10 \\
\hline & < once/year: & 4 \\
\hline & $\geqq$ once/year: & 9 \\
\hline & $\geqq$ once/month : & 11 \\
\hline & $\geqq$ once/week : & 13 \\
\hline $\begin{array}{l}\text { Number of con- } \\
\text { comitant }\end{array}$ & $0:$ & 4 \\
\hline \multirow[t]{3}{*}{ anticonvulsant (s) } & 1: & 18 \\
\hline & $2:$ & 21 \\
\hline & $3:$ & 4 \\
\hline \multirow{3}{*}{$\begin{array}{l}\text { Administration } \\
\text { route }\end{array}$} & Oral : & 34 \\
\hline & $\begin{array}{l}\text { via Nasogastric } \\
\text { tube : }\end{array}$ & 12 \\
\hline & $\begin{array}{l}\text { Dependent on the } \\
\text { condition : }\end{array}$ & 1 \\
\hline
\end{tabular}

* mean \pm S.D. 


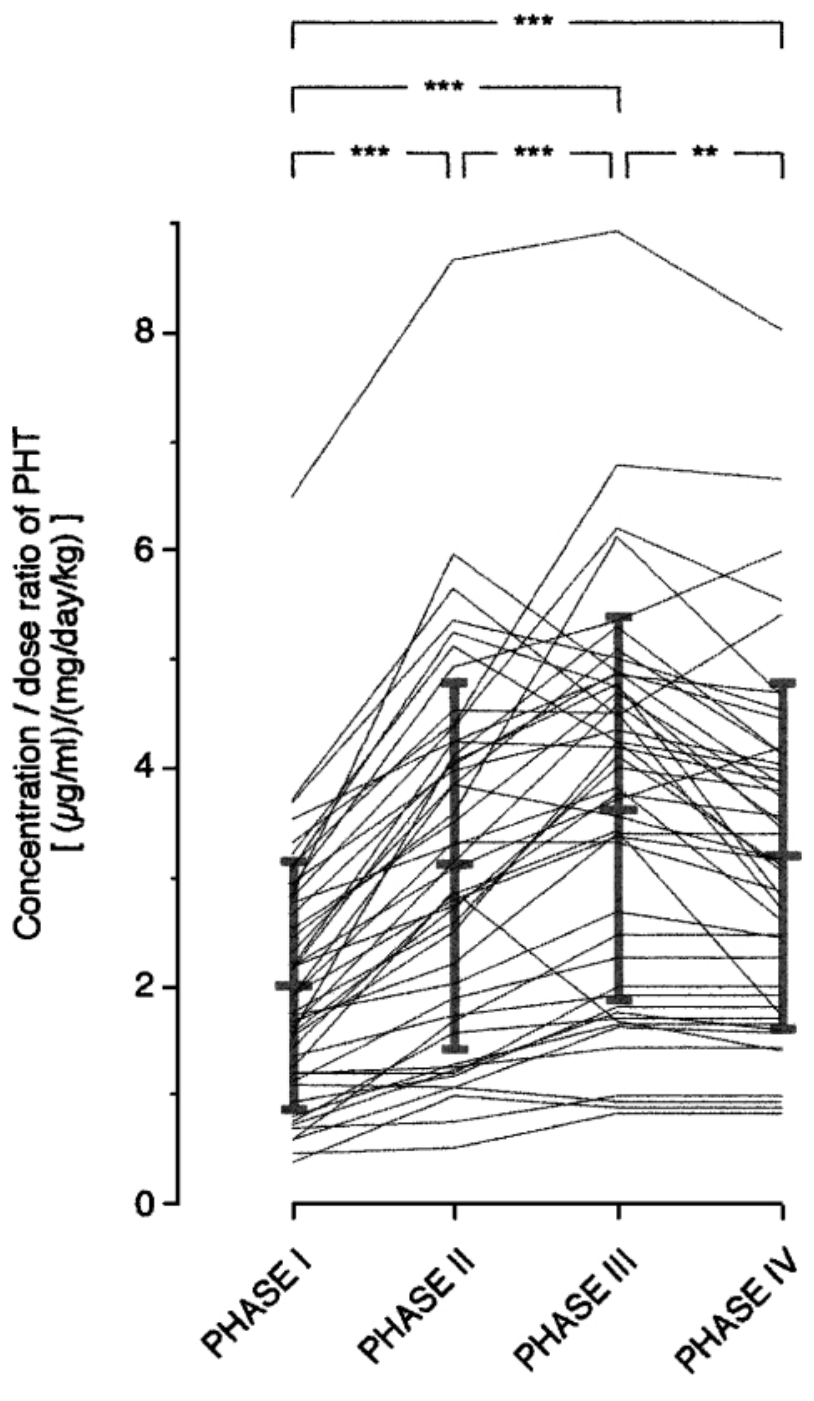

Fig. 2. The Effects of Changes of Dosage Formulation from 97\% Fine Granules (PHASE I) to 97/4\% Hospital-Made Fine Granules (PHASE II), and the Latter to $10 \%$ Powder (PHASE III; before Dose-Adjustment, PHASE IV; after Dose-Adjustment)

Serum PHT concentrations were analyzed in a retrospective manner in 47 inpatients. Statistical significances were determined by repeated measures ANOVA followed by Bonferroni's multiple comparisons test $(* *: p<0.01$, $\left.{ }^{* * *}: p<0.001\right)$.

減量率は $97 \%$ 細粒使用時の投与量の $17.4 \pm 8.3 \%$ (平均值士標準偏差) であった。

2. 分包試験 各製剂, 処方量, 分包紙ごとの 回収率及び摂取率を Table 2 に示す。製剤間比較の 結果， 10 倍散の PHT 摂取率は $98.1 \pm 1.1 \%$ (平均 值士標準偏差）であり，97\% 細粒の摂取率 $84.4 \pm$ $3.6 \%$ （平均值士標準偏差）より有意に高かった $(p<0.01)$. また, 処方量については, 処方量の低 下に伴い摂取率が低下する傾向が認められたもの の，各投与水準間で有意差は認められなかった。一
方，分包紙間では有意差は見られなかった.<smiles>[Mg]</smiles>

当施設における今回の剂形変更において，97\% 細粒から4 倍細粒へと剂形変更した際（Fig. 2, $\mathrm{PHASE} \mathrm{I} \rightarrow \mathrm{PHASE}$ II）に，C/D 比が平均 $55 \%$ 上 昇した。このとき, 対象患者のうち 10 名について は $97 \%$ 細粒を賦形せずに調剂し，他の 37 名につい ては他の薬剤と混合していたが，この 2 群で C/D 比の平均の上昇率には有意差はみられなかった。C /D 比の上昇の要因として，97\% 細粒を賦形するこ とにより製剤の流動性が変化し薬剤の分包紙への残 留が減少した可能性や, 分包紙に残留した製剤の重 量は剂形間で変化しないとしても, 残留する PHT 量は 4 倍細粒では $1 / 4$ に減少するため, 実際に摂取 される PHT が増加した可能性が最も疑わしい. 他 に C/D 比に影響を与える可能性のある要因として は, 院内調製した 4 倍細粒の製剂の不均一性が考え られる。97\% 細粒を乳糖で賦形する際の混合性に ついて, 重松らは EFC (Extra Fine Crystal) 乳糖を 用いて調剤した場合に, より満足できる倍散が得ら れたと述べていることから, 7 当施設でも 4 倍細粒 の調製には EFC 乳糖を用いた。一方，清水らは， 乳糖で賦形した $97 \%$ 細粒は分包誤差が生じやす く，またCF (Crystal Form) 乳糖を用いた際に, 装置瓶を上げ下げする時の外的振動による, 乳糖と

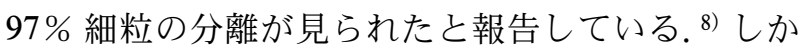
し, 今回の調査の結果, 47 名中 46 名において C/D 比は上昇していた．また，すべての患者は単回投与 ではなく連続投与であるので, PHT の平均含量が 一定であれば，製剤の不均一性が定常状態の血清中 濃度に及ぼす影響は小さいと考えられる。したがっ て, 4 倍細粒への剂形変更によって生じた C/D 比 の上昇の主な要因は, 院内製剤の不均一性によるも のではないと考えられる. 事実, 製剂的に均一性が 保証されている市販 10 倍散への切り替えの際 (Fig. 2, PHASE II $\rightarrow$ PHASE III）にも，ほとんど の患者において C/D 比が再び上昇した，その要因 として 4 倍細粒への剂形変更時と同様, 分包紙に残 留する PHT 量が減少した可能性があげられる。 ま た $97 \%$ 細粒，4 倍細粒のPHT 含量はそれぞれ 100 \%，25\% とみなして調剤されているために，10 倍 散への剂形変更に伴いPHT として約 3\% の増量に 
Table 2. The Influence of Dose, Dosage Form and Package on the Rates of Recovery and Ingestion of PHT (mean \pm S.D.) $(n=5)$

\begin{tabular}{|c|c|c|c|c|c|}
\hline \multirow{3}{*}{ Dosage form } & \multirow{3}{*}{$\begin{array}{c}\text { Dose of PHT } \\
(\mathrm{mg} / \text { day })\end{array}$} & \multicolumn{4}{|c|}{ Package } \\
\hline & & \multicolumn{2}{|c|}{ Diamat } & \multicolumn{2}{|c|}{ Glassine } \\
\hline & & $\begin{array}{c}\text { Rate of } \\
\text { recovery* (\%) }\end{array}$ & $\begin{array}{c}\text { Rate of } \\
\text { ingestion* }(\%)\end{array}$ & $\begin{array}{l}\text { Rate of } \\
\text { recovery* (\%) }\end{array}$ & $\begin{array}{c}\text { Rate of } \\
\text { ingestion* (\%) }\end{array}$ \\
\hline $97 \%$ Fine granules $\left.{ }^{a}\right)$ & 100 & $84.9 \pm 2.4$ & $82.3 \pm 2.3$ & $79.4 \pm 1.6$ & $77.1 \pm 1.6$ \\
\hline $10 \%$ Powder & 100 & $97.7 \pm 0.5$ & $97.7 \pm 0.5$ & $95.6 \pm 0.5$ & $95.6 \pm 0.5$ \\
\hline $97 \%$ Fine granules & 200 & $88.3 \pm 0.4$ & $85.6 \pm 0.4$ & $85.0 \pm 1.8$ & $82.5 \pm 1.7$ \\
\hline $10 \%$ Powder & 200 & $98.1 \pm 0.2$ & $98.1 \pm 0.2$ & $97.6 \pm 0.2$ & $97.6 \pm 0.2$ \\
\hline $97 \%$ Fine granules & 300 & $89.5 \pm 1.1$ & $86.8 \pm 1.1$ & $89.1 \pm 0.6$ & $86.4 \pm 0.6$ \\
\hline $10 \%$ Powder & 300 & $98.9 \pm 0.3$ & $98.9 \pm 0.3$ & $98.7 \pm 0.2$ & $98.7 \pm 0.2$ \\
\hline $97 \%$ Fine granules & 400 & $90.6 \pm 0.5$ & $87.9 \pm 0.5$ & $89.6 \pm 1.0$ & $87.0 \pm 1.0$ \\
\hline $10 \%$ Powder & 400 & $99.1 \pm 0.2$ & $99.1 \pm 0.2$ & $98.9 \pm 0.1$ & $98.9 \pm 0.1$ \\
\hline
\end{tabular}

a) prepared regarding $97 \%$ fine granules as $100 \%$ PHT content.

* Significantly associated with dosage form $(p<0.01$ by three-way ANOVA).

なったことの影響も考えられた.

これらの要因を明らかにするために分包試験を行 つたところ，10 倍散の摂取率は平均 $98.1 \%$ であり, PHT 処方量のほぼ全量が摂取されると考えられた のに対し, 97\% 細粒の回収率は平均 $87.0 \%$, 摂取 率は平均 $84.4 \%$ であった (Table 2). したがって, 10 倍散と $97 \%$ 細粒の PHT 摂取率の比は 98.1/84.4 =1.16 となり, $97 \%$ 細粒から 10 倍散に剂形変更す ることにより, PHT の摂取量としては約 16\% の増 量になったと考えられた。江守らは，97\% 細粒か ら 10 倍散に剂形変更した 12 名の全患者において血 清中濃度の上昇を来たし, 投与量を $97 \%$ 細粒投与 時の平均 $85.1 \%$ に減量することで剂形変更前の PHT 血中濃度を得ることができたと報告している が, 9)これは, 今回の検討における $97 \%$ 細粒の PHT 摂取率の上昇率と極めて良好に対応してい る. 以上のことから, 剂形変更に伴う血清中濃度の 上昇には，回収率の上昇が大きく寄与しているが, 実際の PHT 含量の上昇（約 3\%）も無視できない と思われた。

このような摂取率の変動は PHT 以外の薬物につ いても同様に認められると考えられる.しかし， PHT は治療域において非線型の体内動態を示すこ とから, 摂取率の $16 \%$ の上昇が, PHT の定常状態 下の血清中濃度に及ぼす影響については, 薬物動態 学的側面から考察を行う必要があると思われた。定 常状態下の PHT 血清中濃度と体重あたりの投与量
の関係は，以下の(1)式に従う。

$$
\mathrm{Cs}=\mathrm{Km}{ }^{*} \mathrm{D} /(\operatorname{Vmax}-\mathrm{D})
$$

ここで，D $(\mathrm{mg} / \mathrm{day} / \mathrm{kg})$ は投与量，Cs $(\mu \mathrm{g} / \mathrm{ml})$ は定常状態下の血清中濃度, Vmax $(\mathrm{mg} / \mathrm{day} / \mathrm{kg})$ は最大投与速度, $\mathrm{Km}(\mu \mathrm{g} / \mathrm{ml})$ はミカエリス定数 を表す。 Mamiya らは，遺伝子型毎に日本人におけ る PHT の母集団パラメータを報告しており, PHT の主要な代謝酵素であるチトクローム P-450 (CYP) $2 \mathrm{C} 9$ に変異を有しない $C Y P 2 C 9^{*} 1 /{ }^{*} 1$ 型の 患者における母集団パラメータとして, $\mathrm{Km}=4.0$ $(\mu \mathrm{g} / \mathrm{ml}), \quad \mathrm{Vmax}=6.07(\mathrm{mg} / \mathrm{day} / \mathrm{kg})$ という值を報 告している. ${ }^{10)} こ の$ 遺伝子型を有し $97 \%$ 細粒が投 与されている患者において, Cs $=18(\mu \mathrm{g} / \mathrm{ml})$ を与 える PHT 投与量を求めると, $4.97(\mathrm{mg} / \mathrm{day} / \mathrm{kg})$ となる。ここで $97 \%$ 細粒から 10 倍散へ剂形変更 し，摂取量が $16 \%$ 増加したと仮定して Cs を算出 すると $76.9(\mu \mathrm{g} / \mathrm{ml})$ となる. また， 97\% 細粒投与 時にCs が $7.0(\mu \mathrm{g} / \mathrm{ml})$ であったとすると，10 倍散 に剂形変更後の Cs は $11.3(\mu \mathrm{g} / \mathrm{ml})$ となる. した がって, 血清中濃度が治療濃度下限付近においても, 10 倍散への剂形変更により Cs が $50 \%$ 程度上昇す る可能性があり，ましてや $97 \%$ 細粒投与時の血清 中濃度が高い患者においては, 剂形変更が血清中濃 度の著しい上昇をもたらす危険性が高いと考えられ る。また，当施設では $97 \%$ 細粒から 4 倍細粒に剂 形変更を行った際に投与量調節を行っていたので, 10 倍散への剂形変更に伴う血清中濃度の上昇はあ 
る程度緩和されたが，97\% 細粒から直接 10 倍散へ 剤形変更した場合は，血清中濃度の上昇はより顕著 になり，重篤な中毒症状を惹き起こすことも危惧さ れる。これらのことから，特に $97 \%$ 細粒投与時に 比較的高い血清中濃度でコントロールされている患 者では，TDM（Therapeutic Drug Monitoring）を綿 密に行いながら剤形変更を行うことが, PHT 中毒 を予防する上で重要であると考えられた．また，今 回行った分包試験では，PHT が単剤で分包された 場合についての検討しか行っていない，他の薬剤が 混合されている場合の剂形変更が血清中濃度に及ぼ す影響は不確定なため, 単剂同様 TDM を行いなが ら剤形変更を行うことが望ましいと思われる。ささら に, PHT の各種製剤については今後, 治療域にお ける長期投与下での生物学的同等性を検証すること が必要であると考えられた。

当施設は重症心身障害児（者）〔以下重症児（者）〕 施設であり，入所者の約 70\% がてんかんを基礎疾 患として有している. 重症児（者）の薬物療法にお いては, 抗てんかん薬による痤攣コントロールは大 きな比重を占めており, 中でも PHT は最も繁用さ れている薬剂である。重症児（者）は，体調に変化 を生じても自己表現できず, 薬の副作用や中毒症状 が現れたとしても，本来持っている障害と混同され やすくその識別は困難である，そのため，今回の剂 形変更にあたつては, 血清中濃度のモニターを強化 し, 病棟スタッフに中毒症状に関する情報提供を行 うなど，中毒を未然に防ぐための対策を実施した。 その結果, 重篤な中毒症状を呈した患者は見られな かった。 また，緻密な投与量調節によって，血清中 濃度もすみやかに治療域内に調節することができ た。このように，重症児（者）において PHT の剂 形を変更する際には, 通常のてんかん患者以上の緻 密な TDM を行うべきであると考えられる．また， 当施設には外来は併設されていないが，外来におい て PHT が処方され，中でも来院回数の少ない患者
では，入院患者のように剂形変更後の TDM が十分 に実施されない可能性もあり，重篤な PHT 中毒を 惹き起こす危険性はさらに増大すると思われる.

以上, 本研究により PHT の剂形を $97 \%$ 細粒か ら 10 倍散へと変更するにあたつては, 緻密な TDM を行い血清中濃度の上昇とそれに伴う中毒症 状の発現に細心の注意を払う必要があることが明ら かになった。

\section{REFERENCES}

1) Plaa G. L., Hine C. H., Arch. Int. Pharmacodyn. Ther., 128, 375 (1960).

2) Beselt R. C., Wright J. A., Cravey R. H., Clin. Chem., 21, 44-62 (1975).

3) Kuruvilla T., Bharucha N. E., Epilepsia, 38, 500-502 (1997).

4) Masur H., Elger C. E., Ludlph A. C., Galanski M., Neurology., 39, 432-433 (1989).

5) Boreus L. O., Nergarth A., Ehrnebo M., Theorell K., J. Neurol., 223, 241-249 (1980).

6) Dainippon Pharmaceutical Co., Ltd, Bioavailabilities of ALEVIATIN Fine Granules and ALEVIATIN 10\% Powder.

7) Shigematsu M., Ogawa M., Iwamoto A., Nakagawa H., Ebisawa S., Tanaka T., Miyabe I., Ohnishi N., J. Jpn. Soc. Hosp. Pharm., 26, 865-869 (1990).

8) Shimizu Y., Yano A., Kobayashi H., Yamamoto M., Ishikawa M., Kobayashi S., Inui K., J. Jpn. Soc. Hosp. Pharm., 30, 459462 (1994).

9) Emori K., Okabe A., Tanaka K., Tajiri K., Kurachi M., Abstracts of papers, the 32nd Annual Meeting of Japan Epilepsy Society, Yokohama, 1998, p. 127.

10) Mamiya K., Ieiri I., Shimamoto J., Yukawa E., Imai J., Ninomiya H., Yamada H., Ohtsubo K., Higuchi S., Tashiro N., Epilepsia, 39, 1317-1323 (1998). 